\title{
2nd generation lignocellulosic bioethanol: is torrefaction a possible approach to biomass pretreatment?
}

\author{
David Chiaramonti • Andrea Maria Rizzo • \\ Matteo Prussi • Silvana Tedeschi • \\ Francesco Zimbardi • Giacobbe Braccio • Egidio Viola • \\ Paolo Taddei Pardelli
}

Received: 27 September 2010 /Revised: 9 December 2010 / Accepted: 20 December 2010 /Published online: 15 February 2011

(C) Springer-Verlag 2011

\begin{abstract}
Biomass pretreatement is a key and energyconsuming step for lignocellulosic ethanol production; it is largely responsible for the energy efficiency and economic sustainability of the process. A new approach to biomass pretreatment for the lignocellulosic bioethanol chain could be mild torrefaction. Among other effects, biomass torrefaction improves the grindability of fibrous materials, thus reducing energy demand for grinding the feedstock before hydrolysis, and opens the biomass structure, making this more accessible to enzymes for hydrolysis. The aim of the preliminary experiments carried out was to achieve a first understanding of the possibility to combine torrefaction and hydrolysis for lignocellulosic bioethanol processes, and to evaluate it in terms of sugar and ethanol yields. In addition, the possibility of hydrolyzing the torrefied biomass has not yet been proven. Biomass from olive pruning has been torrefied at different conditions, namely $180-280^{\circ} \mathrm{C}$ for $60-120 \mathrm{~min}$, grinded and then used as substrate in hydrolysis experiments. The bioconversion has been carried out at flask scale using a mixture of cellulosolytic, hemicellulosolitic, $\beta$-glucosidase
\end{abstract}

D. Chiaramonti $(\bowtie) \cdot$ A. M. Rizzo $\cdot$ M. Prussi

CREAR - Research Centre for Renewable Energy and RE-CORD,

University of Florence,

Florence, Italy

e-mail: david.chiaramonti@unifi.it

S. Tedeschi $\cdot$ F. Zimbardi $\cdot$ G. Braccio $\cdot$ E. Viola

ENEA - Laboratory of Technology and Equipment for Bioenergy and Solar Thermal,

C.R. Trisaia, 75026 Rotondella, MT, Italy

P. T. Pardelli

Spike Renewables s.r.1.,

Florence, Italy enzymes, and a commercial strain of Saccharomyces cerevisiae. The experiments demonstrated that torrefied biomass can be enzymatically hydrolyzed and fermented into ethanol, with yields comparable with grinded untreated biomass and saving electrical energy. The comparison between the bioconversion yields achieved using only raw grinded biomass or torrefied and grinded biomass highlighted that: (1) mild torrefaction conditions limit sugar degradation to $5-10 \%$; and (2) torrefied biomass does not lead to enzymatic and fermentation inhibition. Energy consumption for ethanol production has been preliminary estimated, and three different pretreatment steps, i.e., raw biomass grinding, biomass-torrefaction grinding, and steam explosion were compared. Based on preliminary results, steam explosion still has a significant advantage compared to the other two process chains.

Keywords Torrefaction - Lignocellulosic ethanol · Biomass pretreatment $\cdot$ Hydrolysis

\section{Nomenclature \\ GB Grinded biomass \\ OPD Olive pruning debris \\ RM Raw materials \\ SE Steam explosion \\ SEB Steam exploded biomass \\ SHF Separate hydrolysis and fermentation \\ TGB Torrefied and grinded biomass}




\section{Introduction}

The production of olive oil plays a significant role in the economy of the region of Tuscany and therefore in its land use. In 2009, the net amount of surface devoted to the cultivation of Olea europaea for both extraction and direct consumption accounted for almost 92,000 ha, over a total agricultural surface of about 810,000 ha in 2005 . In olivetree cultivation, pruning has to be performed every 2 years in order to obtain good productivity. In this operation, a considerable amount of biomass is produced, thus representing a potential resource for bioenergy generation or biofuel production.

In fact, the use of residues from agriculture and agroindustry as feedstock can improve the economics and the sustainability of producing ethanol from lignocellulosic biomass [1-4].

The first step in the conversion of lignocellulosic biomass to ethanol is pretreatment; feedstock pretreatment has been recognized as a necessary upstream process to alter the structure of cellulose biomass to remove biomass recalcitrance for downstream microbial and enzymatic processing [5]. Biomass pretreatment is a key step for lignocellulosic ethanol production, which absorbs significant amount of energy and is largely responsible for the overall energy efficiency and economic sustainability of the process [6].

Mechanical grinding of biomass as pretreatment for subsequent bioconversion, such as enzymatic hydrolysis and fermentation, must be implemented in order to increase enzyme-accessible surface areas [7]; however, it is characterized by high-energy consumption [8]. A new approach to biomass pretreatment is investigated in this paper for the lignocellulosic bioethanol chain.

Torrefaction is a thermochemical pretreatment method that consists of heating of biomass to a moderate temperature of 200 to $300^{\circ} \mathrm{C}$ in an inert atmosphere [911]. The process reduces the biomass moisture content to extremely low values and increases the energy density as well as the grindability of the material [12, 13]; electricity consumption for size reduction of torrefied wood can be reduced by $50-85 \%$ compared to fresh wood. [14, 15]

The main aim of the experiments that were carried out was to preliminary investigate the effect of coupling torrefaction and grinding, so to verify the enzyme capability of attacking the torrefied feedstock, as well as the sugars and ethanol yields. No much experience exists concerning torrefaction as pretreatment of biomass in the lignocellulosic ethanol chain.

Biomass obtained from olive pruning has been torrefied at different conditions, namely $180-280^{\circ} \mathrm{C}$ for $60-120 \mathrm{~min}$, mill-grinded and sieved at 50 mesh $(0.32 \mathrm{~mm})$, and used as substrate in separate hydrolysis and fermentation (SHF) experiments. In order to limit the degradation of sugars, experiments were carried out at slightly lower temperatures than those reported in previous studies $\left(225-300^{\circ} \mathrm{C}\right)[8,9]$. A recent study on the impact of the torrefaction on lignocellulosic structures confirmed that light torrefaction is an interesting operation in pretreatment of biomass for biofuel production [16].

In order to investigate the effects of torrefaction on the bioconversion phase, SHF experiments have been also carried out on grinded only biomass. The experimental plan is showed in Fig. 1.

\section{Material and methods}

\subsection{Raw material}

Few kilograms of olive pruning debris (OPD) were collected in a farm near Florence, Italy. Only thin branches were retained (1-5 cm in length) along with some cutting residue, and the leaves were eliminated. The biomass sample was collected from a large amount (several tons) of residues stored at the farm site for some months under a roof cover. Prior to torrefaction, the OPD were oven-dried at a temperature of $80^{\circ} \mathrm{C}$ for $24 \mathrm{~h}$.

The composition of the raw material, in terms of hemicellulose, cellulose, and lignin fraction, is reported in Table 1.

In order to carry out the chemical analysis, olive pruning debris was grounded with a rotary mill equipped with a 50 mesh $(0.32 \mathrm{~mm})$ sieve. The ash content of the raw and torrefied materials was determined by sample combustion at $600^{\circ} \mathrm{C}$ (ASTM-1106, modified). Organic soluble extractives were determined by Soxhlet extraction using a

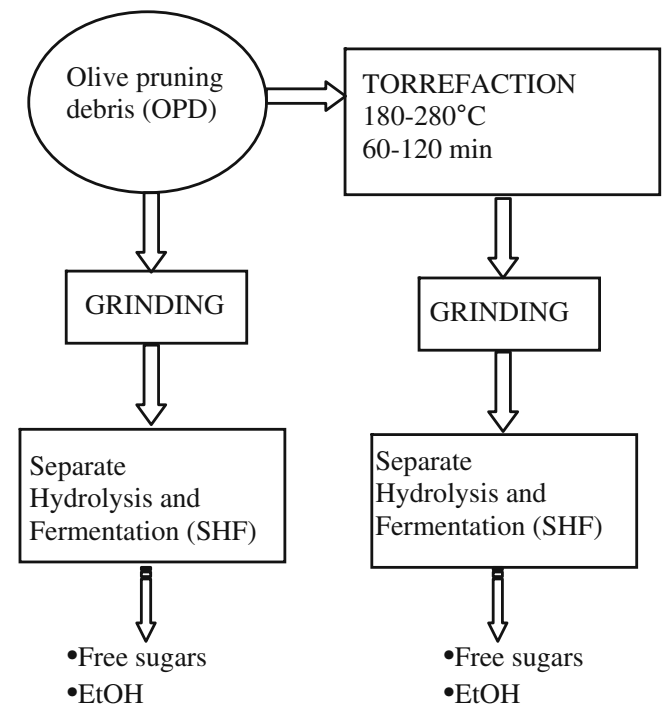

Fig. 1 Layout of the experimental plan 
Table 1 Composition of the olive pruning debris

$D M$ dry matter, $N D$ not determined

mixture of toluene and ethanol 2:1 for $6 \mathrm{~h}$ (ASTM D1106). The extractive free residue was hydrolyzed following the Klason method (TAPPI T13 m-54). Glucose, cellobiose, galactose, xylose, and arabinose in the liquid fraction, were determined by HPIC using an amperometric detector. The sugar degradation during the Klason procedure was accounted for by introducing experimental coefficients.

\subsection{Experimental apparatus for torrefaction}

Torrefaction tests were conducted in a batch reactor composed of a stainless steel cylinder with flanged openings on both sides. The net internal capacity of the cylinder was 11 . Both flanges had a central threaded hole of $12.7 \mathrm{~mm}(1 / 2 \mathrm{inch})$ diameter, which could be fitted either with a valve, a plug, or a special plug featuring an aperture of $1 \mathrm{~mm}$ in diameter. This special plug was used instead of a pressure relief valve as a cost-effective alternative for discharging the vapors produced during torrefaction. The second 1/2-inch aperture of the reactor was then fitted with a plug. In such configuration, the gas expansion in the heating up of the reactor and the vapors produced during the torrefaction of OPD were sufficient to keep the reactor oxygen-free (anaerobic conditions), that would lead to some oxidation of the hot biomass. By connecting one side of the reactor to the nitrogen line and fitting the other with the $1-\mathrm{mm}$ hole plug, it is possible to purge the reactor volume. A schematic drawing of the torrefaction reactor in the purge configuration is reported in Fig. 2.

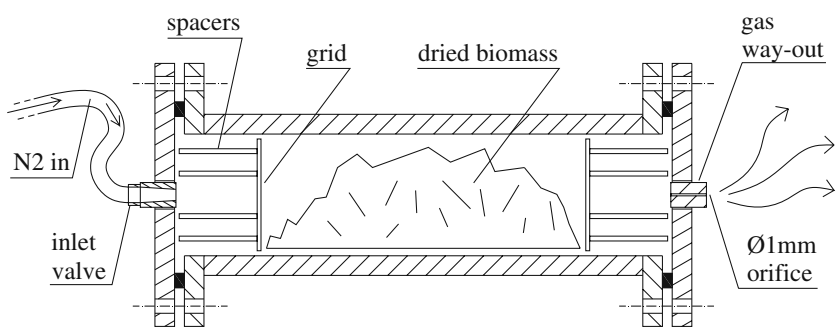

Fig. 2 Sketch of the torrefaction reactor fitted with the nitrogen line to purge the oxygen before processing the biomass
The heat source for the torrefaction tests was a laboratory convective oven, rated for a maximum operating temperature of $400^{\circ} \mathrm{C}$ and fitted with a thermostatic control of the internal temperature. Air circulation inside the oven was provided by a fan. A schematic of the oven and the reactor is reported in Fig. 3. During torrefaction, some vapors and permanent gases are produced (mainly water vapor, acetic acid, $\mathrm{CO}_{2}$, methanol, $\mathrm{CO}$, and some other minor constituents) which both originate from expulsion of residual bonded water and from the degradation of wood. In our test facility, this gas phase was expelled from the reactor, collected from an extractor fan, and directed to the ambient after being burned.

\subsection{Torrefaction test procedure}

The test procedure for each run was as follows:

- The oven was warmed-up to the desired process temperature.

- The reactor was placed in the oven and left there for $4 \mathrm{~h}$ to heat up.

- The reactor was removed from the oven, and the raw biomass was weighed (110-140 g per run) and placed inside the reactor.

- The reactor was connected to the laboratory's nitrogen line through one of the $1 / 2$-inch holes of the reactor's flanges, while the second $1 / 2$-inch opening of the reactor was fitted with a special plug that could allow the gas to escape from it.

- A 4 min nitrogen flushing was performed to ensure that most of the oxygen trapped inside the reactor could be substituted by inert gas.

- Once the nitrogen line was removed, the hole was closed with a conical plug, and the reactor was placed in the oven.

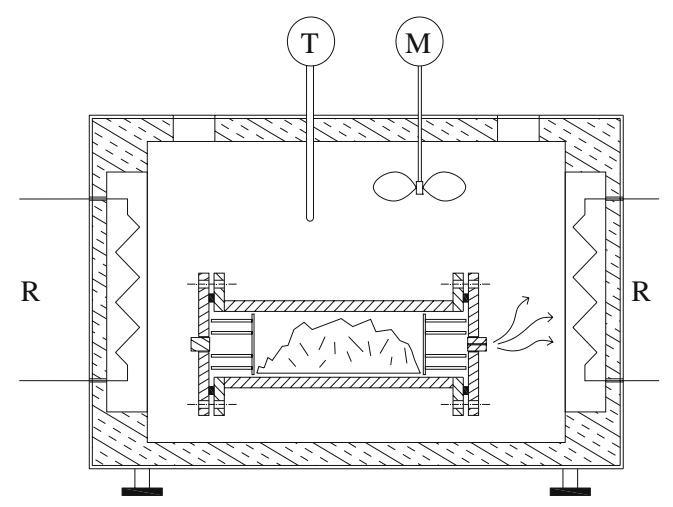

Fig. 3 Convective oven for torrefaction tests. $\mathrm{M}$ is the fan motor, $\mathrm{T}$ is the thermostatic control of temperature, and $\mathrm{R}$ are the electrical resistors. Vapors and permanent gases from torrefaction are expelled from the top apertures 
Fig. 4 Sketch of the hydrolysis and fermentation procedures

\section{$100 \mathrm{ml}$ flask}

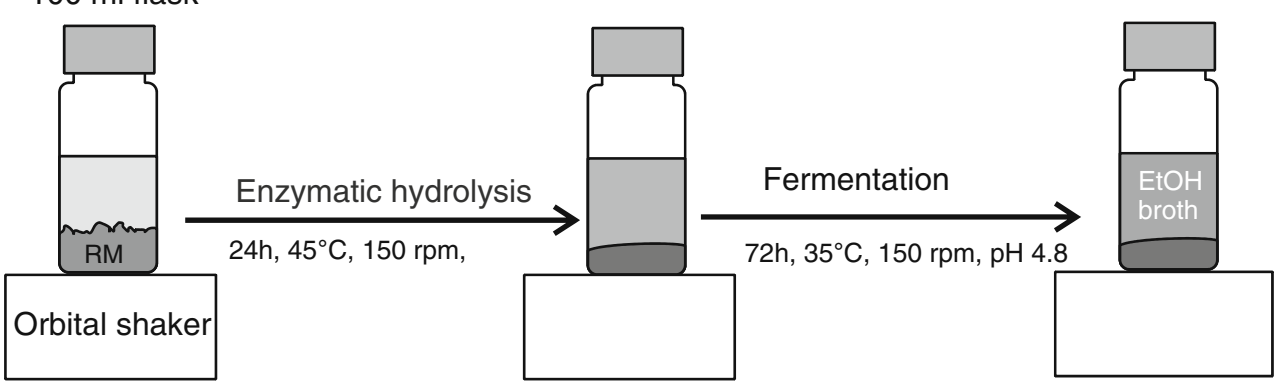

- The starting time was conventionally assumed to be the moment when the oven's thermostat reached the setpoint temperature.

- A fast cooling down of the treated biomass was performed by a second nitrogen flushing, prior to further weighing.

Weighing of the torrefied material has been performed with a laboratory class balance ( $0.1 \mathrm{~g}$ resolution).

\subsection{Hydrolysis and fermentation}

The torrefied biomass was grinded with the same procedure and equipment used to mill raw material and used as a substrate in hydrolysis and fermentation experiments. The bioconversion was constituted of a fast separate hydrolysis at $45^{\circ} \mathrm{C}$ for $24 \mathrm{~h}$ and in a simultaneous hydrolysis and fermentation for further $72 \mathrm{~h}$ in order to optimize the action of the enzymes (Fig. 4). Raw and torrefied samples, both milled, were hydrolyzed with the commercial cellulose mixture of Celluclast $1.5 \mathrm{~L}$ (65 FPU/g and $17 \beta$-glucosidase IU/g), supplemented with the $\beta$-glucosidase Novozyme 188 (376 $\beta$-glucosidase IU/g) from Novozymes A/S (Bagsværd, Denmark), and fermented with Saccharomyces cerevisiae (SIGMA II Type). Enzymatic hydrolysis was carried out at a $5 \%(\mathrm{w} / \mathrm{v})$ consistency in a solution containing $1.65 \mathrm{~g} / 1$ of Celluclast and $0.33 \mathrm{~g} / 1$ Novozym (both expressed as protein; the protein content is $125 \mathrm{mg}$ per $\mathrm{g}$ of enzyme) and $0.1 \mathrm{M} \mathrm{NaAc}$ buffer to a total mass of $50 \mathrm{~g}$, in a closed bottle of $100 \mathrm{ml}$. Hydrolysis was performed at $45^{\circ} \mathrm{C}$ and $\mathrm{pH} 4.8$, with a shaking rate of $150 \mathrm{rpm}$, for $24 \mathrm{~h}$. After $24 \mathrm{~h}$, the hydrolysate was supplemented with additional nutrients to provide a base medium composition of: $3 \mathrm{~g} / 1$ of yeast, $2.5 \mathrm{~g} / 1$ of yeast extract, $0.25 \mathrm{~g} / 1\left(\mathrm{NH}_{4}\right)_{2} \mathrm{HPO}_{4}$, and $0.025 \mathrm{~g} / 1 \mathrm{MgSO}_{4} \cdot \mathrm{H}_{2} \mathrm{O}$. All fermentations were carried out at $35^{\circ} \mathrm{C}, \mathrm{pH} 4.8$, with a shaking rate of $150 \mathrm{rpm}$. Samples were withdrawn at regular time intervals for $72 \mathrm{~h}$ for sugars and ethanol analysis. All experiments were performed in duplicate, analytical determination in triplicate, and average values are reported.

\section{Results and discussion}

\subsection{Torrefaction results}

For this study, three residence times (60-90-120 min) and five torrefaction temperatures $\left(180-220-240-260-280^{\circ} \mathrm{C}\right)$ were considered, for a total of 12 runs. For each run, the raw material was oven-dried at $80^{\circ} \mathrm{C}$ for $24 \mathrm{~h}$ before being processed. A resume of the mass losses for selected and representative runs (four of which result of double experiments), is reported in Table 2.

After weighing, the samples were collected, cooled down, vacuum sealed, and stored at room temperature for further manipulation and analysis.

\subsection{SHF results}

In the flasks loaded with grinded and torrefied biomass at severe conditions $\left(240-280^{\circ} \mathrm{C}\right)$, no ethanol was detected (Fig. 5); only a very limited hydrolysis of the cellulose has been obtained in this test. Instead, mild torrefaction conditions $\left(180-220^{\circ} \mathrm{C}\right)$ generated higher hydrolysis yields (calculated by stoichiometry on the basis of the cellulose in

Table 2 Mass losses of OPD after torrefaction

\begin{tabular}{lcrcc}
\hline$T\left[{ }^{\circ} \mathrm{C}\right]$ & Time $[\mathrm{min}]$ & $m_{1}[\mathrm{~g}]$ & $m_{2}[\mathrm{~g}]$ & $\Delta m[\%]$ \\
\hline 180 & 60 & 139.4 & 137.9 & 1.1 \\
180 & 90 & 155.2 & 150.8 & 2.8 \\
220 & 60 & 127.1 & 119.4 & 6.1 \\
220 & 90 & 143.7 & 132.0 & 8.1 \\
240 & 90 & 97.7 & 82.9 & 15.1 \\
240 & 90 & 110.5 & 92.3 & 16.5 \\
260 & 90 & 90.3 & 75.4 & 16.5 \\
260 & 90 & 107.3 & 88.7 & 17.3 \\
260 & 120 & 107.3 & 82.4 & 23.2 \\
260 & 120 & 94.4 & 75.4 & 20.1 \\
280 & 90 & 103.8 & 79.3 & 23.6 \\
280 & 90 & 102.7 & 78.9 & 23.2 \\
\hline
\end{tabular}

$T$ temperature 
Fig. 5 Glucose (after 48 h, before fermentation) and ethanol recovery (after $72 \mathrm{~h}$ ) in torrefied samples after enzymatic hydrolysis and fermentation in percent

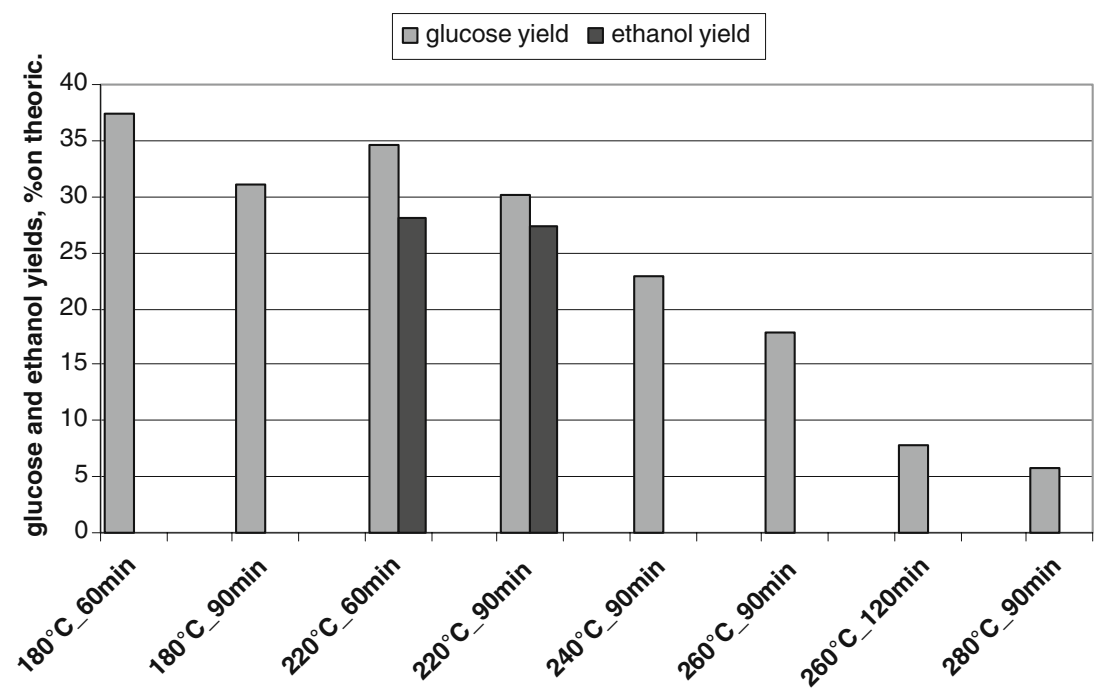

the raw material) and, in the case of $220^{\circ} \mathrm{C}$ torrefied sample, fermentation inhibition was not detected for both the residence times (i.e., 60 and $90 \mathrm{~min}$ ).

In fact, the comparison between the bioconversion yields achieved using grinded biomass or torrefied and grinded biomass highlighted that the torrefaction process at mild conditions slightly affects the enzymatic hydrolysis (decreasing from 39 to $35 \%$ ), and leads to ethanol yields comparable to those obtained by the fermentation of simply grinded biomass (Fig. 6).

\subsection{Energy balance of pretreatments: steam explosion versus grinding and torrefaction}

The use of fresh and torrefied biomass could also be compared with one of the currently most promising pretreatment process, i.e., steam explosions (SE). A summary of the three process paths that were investigated

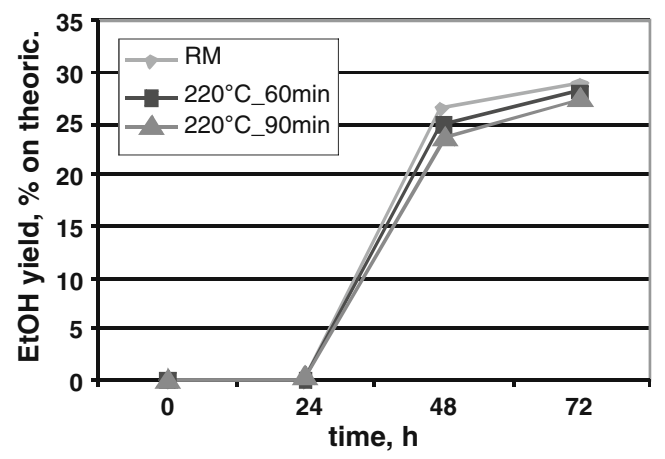

Fig. 6 Ethanol yields achieved in the SHF of the raw material (RM) and OPD torrefied at $220^{\circ} \mathrm{C}$ for 60 and $90 \mathrm{~min}$, calculated on with respect to the cellulose content of the feedstock (maximum theoretical attainable) in this study as well as the main energy figures are given in Fig. 7.

Based on the data available in literature for representative SE process $[15,17,18]$, the thermal energy demand for steam generation ranges between 0.9 [19] and $2.7 \mathrm{MJ}_{\text {th }}[18]$ per $\mathrm{kg}$ of processed biomass. The lower figure has been adopted in this research work, which corresponds to $0.3 \mathrm{~kg}$ of steam per $\mathrm{kg}$ of biomass. Assuming the steam being produced by burning biomass (LHV $12.23 \mathrm{MJ} / \mathrm{kg}$ at $15 \% \mathrm{~m}$. c.) in a boiler, and considering a steam generator's efficiency of $90 \%$, the gross thermal input for steam production ranges between 1 and $3 \mathrm{MJ}_{\text {th. }}$. Basing on measurement on a pilot plant, the electrical input for SE has been estimated equals to $1.1 \mathrm{MJ}_{\mathrm{el}}$ per $\mathrm{kg}$ of biomass [18].

As regards to the second and third process paths, i.e., grinded biomass (GB) and torrefied and grinded biomass (TGB), the energy required for grinding to obtain a particle size below $500 \mu \mathrm{m}$ [assuming $15 \%$ initial moisture content of the raw materials (RM)] has been taken from recent literature on torrefaction with spruce as feedstock [13]. Reported values range from $750-850 \mathrm{kWh}_{\mathrm{el}} / \mathrm{t}$, i.e., 2.70 $3.06 \mathrm{MJ}_{\mathrm{e}} / \mathrm{kg}$ for RM, while torrefied biomass requires as low as $250 \mathrm{kWh}_{\mathrm{el}} /$ t, i.e., $0.90 \mathrm{MJ}_{\mathrm{el}} / \mathrm{kg}$. An average figure of $2.88 \mathrm{MJ}_{\mathrm{el}} / \mathrm{kg}$ was here assumed for $\mathrm{RM}$; in general terms, the electric energy consumption for fine grinding of torrefied biomass is approximately $30 \%$ of fresh biomass. This is due to the rather mild torrefaction approach used in this work, and the figure becomes even lower in case of torrefaction at or above $280^{\circ} \mathrm{C}$. It was assumed to operate the torrefier at autothermal conditions $[15,17]$, i.e., the torrefaction gas exactly provides the energy content needed to carry out the torrefaction process, and therefore the thermal input for the process is negligible, which means that the energy input for the process is solely electrical. A limited amount of heat needs to be supplied only during the start-up phases. 


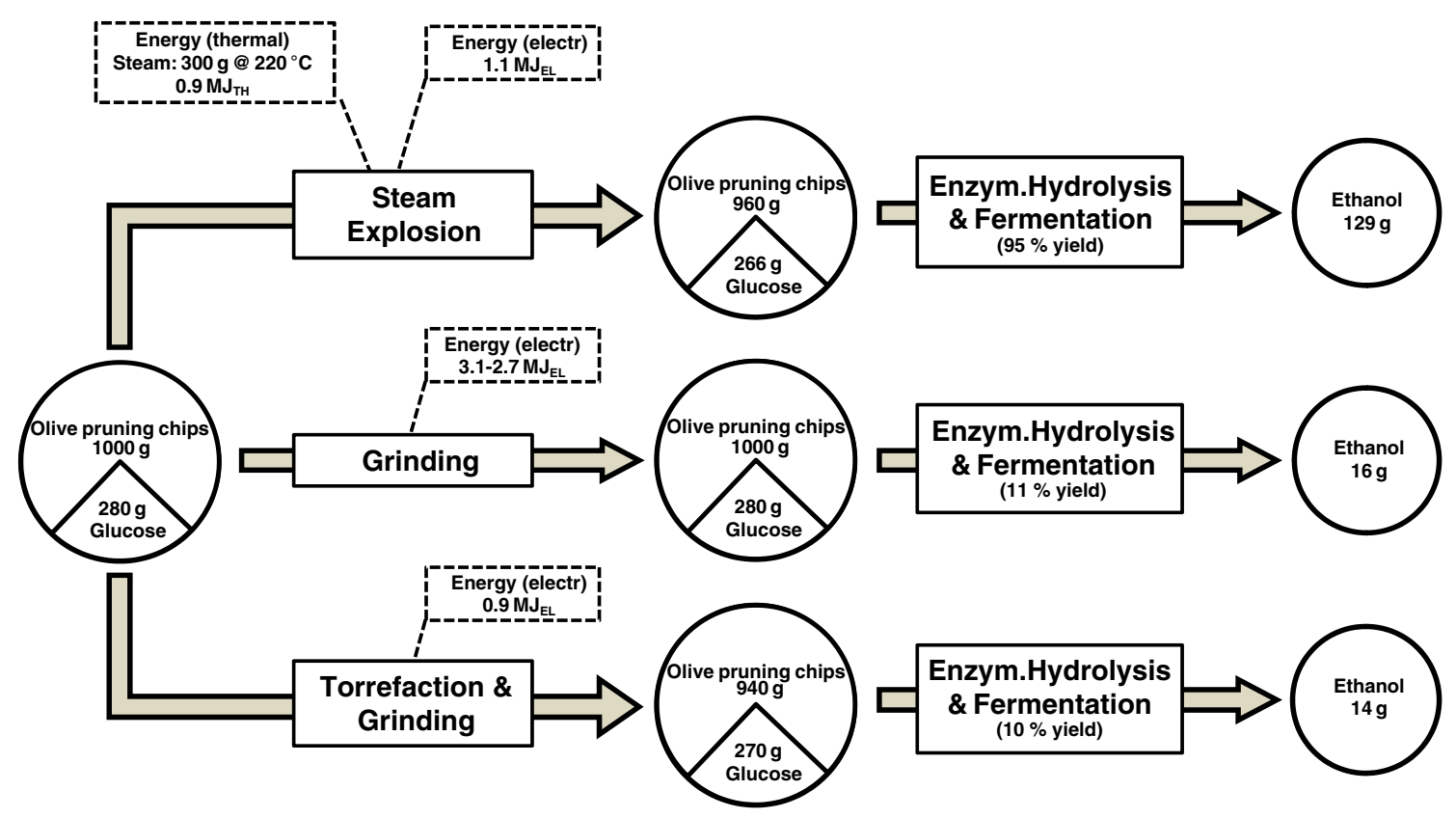

Fig. 7 Comparison of different process options: ethanol yield (referred to $1,000 \mathrm{~g}$ of initial dry matter and energy requirement for steam SE, GB, and TGB process paths. The electrical energy for steam explosion is inferred from measurement on a pilot plant and comprises a bland grinding to reduce chips size [18]. The thermal energy for steam was calculated as $\Delta H$ from water at $15^{\circ} \mathrm{C}$ to steam at $220^{\circ} \mathrm{C}$. Electrical energy input for GB and TGB is derived from literature [13]
As shown in the Fig. 7 and taking into account the cellulose content only, both the GB and TGB process routes give a very low ethanol yield, compared to the theoretical yield from steam exploded biomass, $11.4 \%$ and $10.1 \%$, respectively, while SE attains approximately 95\%. Hydrolysis efficiency is here theoretically assumed equals to $100 \%$ (it could be 90 to $70 \%$ on cellulose, depending on the process severity). This results in ethanol yields for the three paths [steam exploded biomass (SEB), GB, and TGB] of $0.129,0.016$, and $0.014 \mathrm{~kg}$ per $\mathrm{kg}$ of dry biomass, respectively. Calculating the energy per $\mathrm{kg}$ of ethanol for each process path as the ratio of either thermal or electrical energy input to the mass of produced ethanol, for TGB and GB paths ones, respectively, obtains 64.29 and $180 \mathrm{MJ}_{\mathrm{el}} / \mathrm{kg}$ of $\mathrm{EtOH}$; therefore, torrefaction leads to a net saving in high-value electrical energy in the order of $64 \%$ when compared to the GB chain. If instead SEB is compared to GB and TGB, the extremely high efficiencies of the hydrolysis and fermentation phases on SEB make the comparison very unfavorable for the counterpart since SE is accounted for an energy-to-ethanol value of $8.53 \mathrm{MJ}_{\mathrm{el}}$ plus $7.75 \mathrm{MJ}_{\text {th }}$ per $\mathrm{kg}$ of EtOH. Results are summarized in the following Table 3 .

The yield of ethanol in SE is therefore one order of magnitude higher than GB or TGB paths which is mainly due to the combination of a hydrolytic and mechanical effect of steam explosion at the same process temperature.
The performances of the TGB process could be further improved by optimizing the torrefaction-operating parameters, by recovering some of the available energy from cooling of torrefied biomass, and by assessing - on the long term-the effect due to inhibitor formation, that are expected to be higher for the GB than the TGB, and also considerable for the SEB. Moreover, a detailed study on the energy requirements for the SHF phase should be carried out, as any variation on this energy demand changes the final balance in terms of $\mathrm{MJ} / \mathrm{kg} \mathrm{EtOH}$.

This analysis focused on the sole cellulose fraction. However, the impact of these processes on the hemicelluloses phase should also be evaluated. As the decomposition of the hemicellulose is responsible for most of the

Table 3 Energy requirements per $\mathrm{kg}$ of ethanol for various pretreated biomasses subject to SHF

\begin{tabular}{lcl}
\hline $\begin{array}{l}\text { Pretreated } \\
\text { feedstock }\end{array}$ & $\begin{array}{l}\text { Electrical energy } \\
\text { demand }\left(\mathrm{MJ}_{\mathrm{el}} / \mathrm{kg}\right)\end{array}$ & $\begin{array}{l}\text { Thermal energy demand } \\
\left(\mathrm{MJ}_{\mathrm{th}} / \mathrm{kg}\right)\end{array}$ \\
\hline $\mathrm{GB}$ & 180.00 & $\sim 0$ \\
$\mathrm{TGB}$ & 64.29 & $\sim 0$ \\
$\mathrm{SEB}$ & 8.53 & 7.75 \\
\hline
\end{tabular}

$G B$ grinded biomass, $T G B$ torrefied and grinded biomass, $S E B$ steam exploded biomass 
inhibitor formation, and it is also linked to the process severity which determines the recovery of C5 and C6 sugars, this evaluation can be very complex. Mild torrefaction will limit the losses of hemicelluloses, that means lower EtOH yield, but will also contribute to a reduction of inhibitor formation, as part of these are devolatized during the thermal treatment. Thus, further studies are needed to assess these effects.

\section{Conclusions}

The experiments demonstrated that torrefaction leads to materials which can be enzymatically hydrolyzed and fermented into ethanol with yields comparable to raw biomass.

The energy demand for lignocellulosic bioethanol produced from torrefied biomass is lower than the case of raw biomass chains. The overall energy consumption per $\mathrm{kg}$ of ethanol has been estimated for three different process paths, namely steam explosion, grinding of torrefied biomass, and grinding of raw biomass which resulted respectively in $8.53 \mathrm{MJ}_{\mathrm{el}}$ and $7.75 \mathrm{MJ}_{\mathrm{th}}, 64.29 \mathrm{MJ}_{\mathrm{el}}$, and $180 \mathrm{MJ}_{\mathrm{el}}$ per $\mathrm{kg}$ of EtOH. Further room for optimization exists for the new approach investigated in this research work, as only preliminary experiments have been carried out so far.

Even examining only the glucose fraction of the biomass at inlet, torrefaction is considerably less energy efficient than SE due to lower efficiencies in hydrolysis and fermentation. This finding is expected to occur even if the process is optimized, and the energy streams are recovered and well integrated in the overall scheme. However, the integration with other treatments on torrefied feedstock is still to be investigated.

In order to reduce inhibitor formation and C5 loss, optimum process conditions have to be defined. In the present work, mild torrefaction conditions were investigated; so far, the best conditions were identified at $220^{\circ} \mathrm{C}$ at $60 \mathrm{~min}$, but further research is needed to investigate the several components affecting the final ethanol yield.

After having demonstrated that torrefied biomass can be enzymatically hydrolyzed, the possibility to improve hydrolysis and fermentation efficiencies will need further and dedicated investigation.

Acknowledgments Authors wish to acknowledge Prof. Ing. Francesco Martelli, Director of CREAR-University of Florence, for the suggestions and contributions to the present research work.

\section{References}

1. Romero I et al (2007) Ethanolic fermentation of phosphoric acid hydrolysates from olive tree pruning. Ind Crops Prod 25(2):160-168

2. Hahn-Hagerdal B, Galbe M, Gorwa-Grauslund MF, Lidén G, Zacchi G (2006) Bio-ethanol-the fuel of tomorrow from the residues of today. Trends Biotechnol 24:549-556

3. Scharlermann JPW, Laurance WF (2008) How green are biofuel? Science 319:43-44

4. von Blottnitz H, Curran MA (2007) A review of assessment conducted on bio-ethanol as a transportation fuel from a net energy, greenhouse gas, and environmental life cycle perspective. J Cleaner Prod 17:607-619

5. Hendrixs ATWM, Zeeman G (2009) Pretreatments to enhance the digestibility of lignocellulosic biomass. Bioresour Technol 100:10-18

6. Yang B, Wyman CE (2008) Pretreatment: the key to unlocking low-cost cellulosic ethanol. Biofuels Bioproductsand Biorefining 2:26-40

7. Zhun JY, Wang GS, Pan XY, Gleisner R (2009) Specific surface for evaluating wood size-reduction and pretreatment efficiencies. Chem Eng Sci 64:474-485

8. Zhu JY, Pan XJ (2010) Woody biomass pretreatment for cellulosic ethanol production: technology and energy consumption evaluation. Bioresour Technol 101:4992-5002

9. Prins MJ, Ptasinski KJ, Janssen FJJG (2006) Torrefaction of wood, part 1 weight loss kinetics. J Anal Appl Pyrol 77:28-34

10. Sadaka S, Negi S (2009) Improvements of biomass physical and termochemical characteristics via torrefaction process. Environ Prog Sustainable Energy 28(3):427-434

11. Deng J, Wang G, Kuang J, Zhang Y, Luo Y (2009) Pretreatment of agricultural residues for co-gasification via torrefaction. J Anal Appl Pyrol 86:331-337

12. Arias B, Pevida C, Fermoso J, Plaza MG, Rubiera F, Pis JJ (2008) Influence of torrefaction on the grindability and reactivity of woody biomass. Fuel Process Technol 89:169-175

13. Repellin V, Govin A, Rolland M, Guyonnet R (2010) Energy requirement for fine grinding of torrefied wood. Biomass and Bioenergy 34(7):923-930

14. Bergman PCA, Boersma AR, Kiel JHA, Prins MJ, Ptasinski KJ, Janssen FJJG (2004) Torrefaction for entrained flow gasification of biomass. In: Van Swaaij WPM, Fjallstrom T, Helm P, Grassi A (eds) Second world biomass conference. ETA-Florence and WIPMunich, Rome, pp 679-682

15. Bergman PCA, Kiel JHA (2005) Torrefaction for biomass upgrading. In: Proceedings of the fourteenth European biomass conference and exhibition, Paris, France, 17-21 October 2005

16. Chen W-H, Kuo P-C (2010) A study on torrefaction of various biomass materials and its impact on lignocellulosic structure simulated by a thermogravimetry. Energy 35(6):2580-2586

17. Uslu A, Faaji APC, Bergman PCA (2008) Pre-treatment technologies, and their effect on international bioenergy supply chain logistics. techno-economic evaluation of torrefaction, fast pyrolysis and pelletisation. Energy 33:1206-1223

18. Zimbardi F, Ricci E, Braccio G (2002) Technoeconomic study on steam explosion application in biomass processing. Appl Biochem Biotechnol 98-100:89-99

19. Steam explosion techniques: fundamentals and industrial applications, edited by B. Focher and Annamaria Marzetti October 20 21, 1988, Milan, Italy 